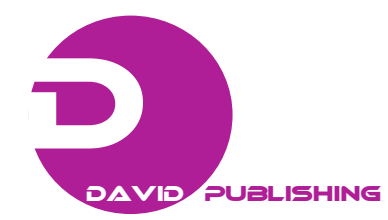

\title{
Effect of Four Selected Chemicals on the Incidence and Severity of Mungbean Yellow Mosaic Virus and Its Relation to the Seed Yield of Mungbean
}

\author{
A.H.M. Mahfuzul Haque*¹, Mohd. Mostafa Kamal² and Abdul Mannan Akhanda ${ }^{3}$ \\ 1, 2. Pulses Research Centre, Bangladesh Agricultural Research Institute (BARI), Gazipur 1701, Bangladesh \\ 3. Bangabandhu Sheikh Mujibur Rahman Agricultural University (BSMRAU), Salna, Gazipur 1706, Bangladesh \\ *Corresponding author’s e-mail:mahfuzprc@gmail.com
}

\begin{abstract}
A field experiment was conducted at Bangladesh Agricultural Research Institute, Joydebpur, Gazipur, Bangladesh during March to June 2008 for the management of mungbean yellow mosaic virus through four selected chemicals on BARImung 4. The four selected chemicals were Furadan 5G (carbofuran), Dursban 20EC (chloropyrifos), Ripcord 10EC (cypermethrin) and Admire 200SL (imidachloprid). At 50DAS the lowest disease incidence and severity were recorded for admire received plants and the highest was found in control. A strong positive correlation existed between the population of whitefly and mungbean yellow mosaic virus incidence while negative correlation performed by mungbean yellow mosaic virus incidence and total seed yield. The total seed yield was highest in the Admire treated plants and the lowest was found in the control plot. All the chemicals performed better in reducing disease incidence and severity comparing with control but Admire (imidachloprid) achieved the best results in which disease incidence was reduced by $30.86 \%$ and the yield was increased by $20.06 \%$.
\end{abstract}

Key words: Mung bean, yellow mosaic virus, seed yield, selected chemical, Bangladesh. 